\title{
Concept of Vertical Village as DAS Brantas Resilience Settlement Strategy in Pandemic Era
}

\author{
Hana Hali Nurahmada ${ }^{1, *}$ Tarranita Kusumadewi ${ }^{1 *}$, Agus Subaqin ${ }^{1}$ \\ ${ }^{1}$ Department of Architecture Engineering, Faculty Science and Technology, UIN Malang Indonesia \\ "Corresponding author.Email: hanahalinurr@gmail.com tarranita@gmail.com tarra_nita@arch.uin-malang.ac.id
}

\begin{abstract}
The vertical village concept is the vertical arrangement of settlement, which maintains the character of a village. The vertical village concept's design can be a solution for the dense population in DAS Brantas, Malang City. The problems of the slum make the dense settlements in the DAS Brantas have low settlement resilience. This vertical village concept aims to settle settlements in DAS Brantas, both in economic, ecological, social, or economic aspects through a selfsufficient concept design approach. The qualitative method is used to describe the settlement site to get a vertical village concept design strategy. Meanwhile, we use a literature review to get design parameters in concept design. A settlement can meet its own needs by maintaining the balance of the ecosystem between land and river ecosystems is a parameter design of this vertical village concept. So this design applies the residents' local character such as entrepreneurs spirit as traders and knowledge about planting media. It also makes residential landscapes riparian ecosystems. There are river and land ecosystems, creating the potential of both of them as public spaces served to users by riverfront promenades. It can be an appeal to form thematic village as the city government has planned to tackle slum settlements on the riverbank. The thematic village concept could become a tourist attraction and improve the local community's standard of living and income. That way, this settlement will have good resilience in ecological, economic, health, and social aspects. Resilience settlements will be able to survive in the pandemic era.
\end{abstract}

Keywords: Vertical Village, Settlement, Resilience, Self-Sufficient, Dense Population, Pandemic

\section{INTRODUCTION}

\subsection{Background}

A view of more prosperous city life has become a mindset for Indonesians. This can be seen from the large number of villagers who transmigrate to the city to be more viable. This is one factor in the appearance of the phenomenon of urbanization.

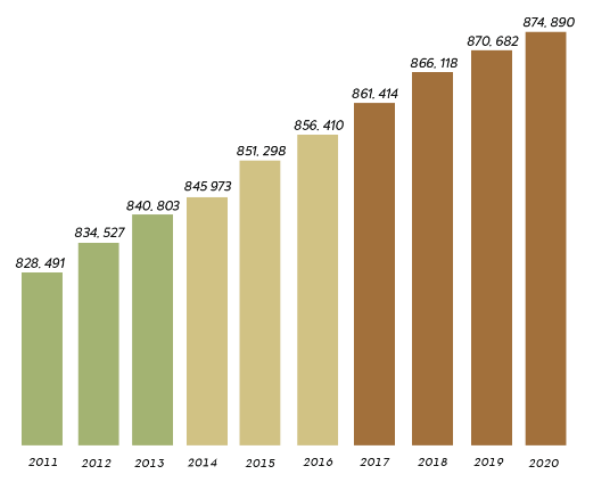

Figure 1. Population Growth Malang City 20112020
The data, depicted in figure 1, shows Malang City population growth, which increases every year due to urbanization. One of them is Kotalama Village, a village with a high population and a high population density. As the growth of the high population increases, so does the need for housing there. As soon as the area's land is the same, then housing needs increase to cause settlement problems that some of them are slum in the riverbank and on the railroad side.

The development of a densely populated area has changed the face of especially in the riverbanks. History has noted that humans chose to live near the rivers to moving water needs, transport, and daily labor. NorbergSchulz points out that riverbank plays an essential role as city infrastructure and also as a place where people meet. In Malang city, settlement can easily be observed in the riverbank. One case study was the settlement in DAS Brantas that run through Muharto road, Malang. In Kotalama village, particularly RW. 5, 6, 7, 8, 9, and 10 are residential areas which border with Brantas river. 
These settlements were categorized as unhealthy houses, considered in Kepmenkes 1999. The settlement is about 1 meter from the river and even no distance directly border with the retaining wall. The condition of settlement with the drainage and sewage systems are thrown directly into the river. Furthermore, the orientation of citizens' settlement that backs on to the river can dodge domestic waste into the river directly. Some citizens also use the riverbank as areas for cooking, washing, and drying clothes. At one time, there had been news of a landslide on the riverbank. From the above phenomena, it shows that settlements in the riverbank have low resilience.

Besides, residents in suburban settlements, including those living in urban slums and informal settlements, are likely to be at high risk of immobility and mortality during the pandemic. [3] With the continuous rise in the global death toll from COVID-19 there is a growing realization that mortal- ity for the SARS-COV-2 virus is inequitably distrib- uted among vulnerable populations. These vulnerable populations may include older adults, people living in densely populated areas, people with lower socioeco- nomic status, migrants and minorities. These groups have higher rates of comorbid chronic conditions, putting them at high-risk for infection and for severe consequences of the disease. According to the previous, population health, economics, and ecology issues are becoming important and critical to the settlement of DAS Brantas. [4] Due to limited land, vertical village planning that can address the high space requirements due to population density is required.

Based on the background above, the formulation of the problems that had been taken in this study is "How is the concept of a vertical village as DAS Brantas resilience strategy in the pandemic era? From the formulation of the problem above, there are two goals to achieve research's goals. First, to identify the potentials and strengths used as a design strategy through SWOT analysis. The second is to conclude the strategy and design concept based on literature review and analysis. To get appropriate criteria, an analysis method related to the issues should be addressed.

\subsection{Location of Research}

The research area's scope is described step by step from the map of Malang to the study area, as described in Figure 1. The study area is a part of the administrative unit at the next-to-lowest level in the City (called RT in native language). The north side of the location is the Brantas River, while another kampung surrounds the east, west, and south. Figure 1 shows that the riverbank located on the north side and a street from east to west, dividing the location into two blocks: north and south.

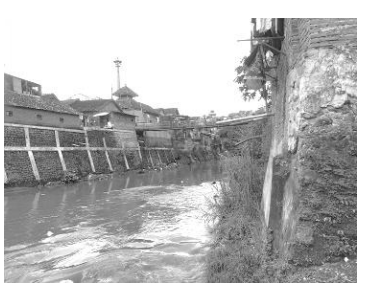

(a)

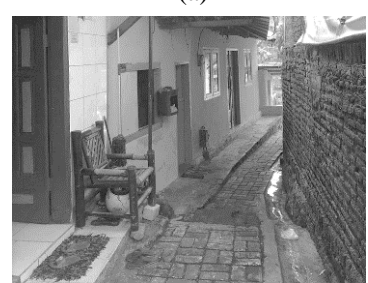

(c)

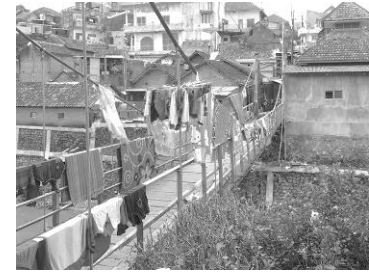

(b)

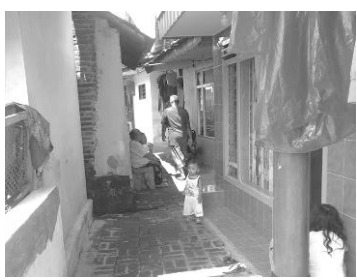

(d)
Figure 2. Kelurahan Kotalama Rt. 5 Rw. 6 Existing

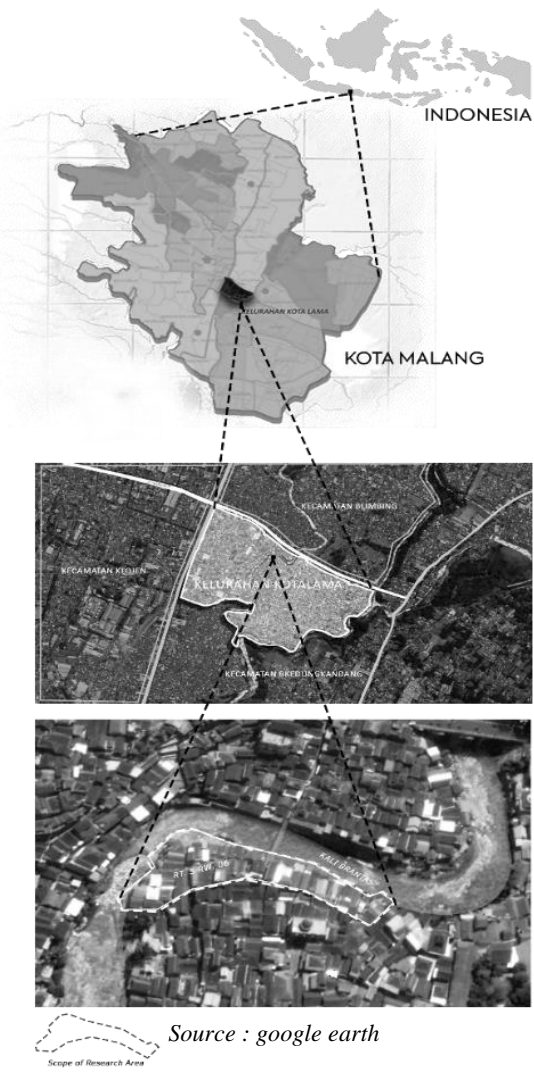

Figure 3 Kotalama Village RT. 5 Rw. 6 as area od study

A general overview of Kelurahan Kotalama RT. 5 RW. 6 can be seen in figure 2. The left (a) and right (b) 
show the existing condition of the riverbank with the retaining wall that continued with the wall of the house building. Furthermore, it shows the bridge which connects between 2 RW. Figure 2 (c) and (d) describe the atmosphere of settlement condition with its small streets between buildings. The street's width is approximately 1 meter with paving materials, as the circulation of motors and people in the settlement.

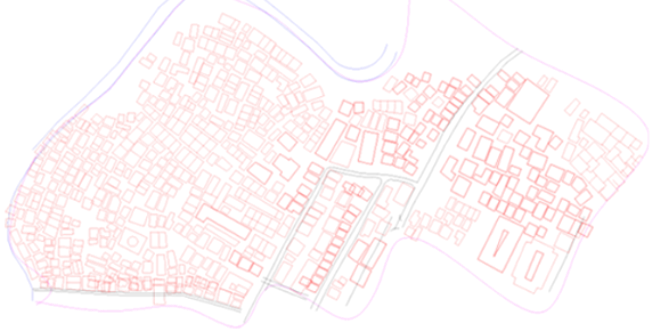

Figure 4. Monography Map of RW 6 Kotalama Village

Based on data from the Kotalama Village office, the highest population and density in the Kedungkandang Sub-district is in the Kotalama Village, with 29. 240 people. The highest number of residents is in RW. 10 (3978 people) and RW. 6 (3.551 people). And the site area study is in RT. 5 Rw. 6 with a total of 34 households [5].

\section{LITERATURE REVIEW}

\subsection{Vertical Village}

The vertical village makes use of a grid-like organization. This organization does not run horizontally, as in a regular city grid. However, it is turned vertically and closed to form a circular entity. The vertical village offers a healthy and individual urban lifestyle characterized by short distances and a mixture of work and living; everything remains decentralized and freely accessible. Furthermore, the vertical village's high-density architecture offers not only a high amenity value and capacity for adaptation but also an enormous economic and ecological potential. This architecture integrates the entire construction morphology through its detailed articulation. The vertical village creates a new kind of urban vision in which robotic technology no longer appears as abstract but as a realistic means of designing and building and arriving at novel architectural paradigms [6].

\subsection{River Green Open Space}

According to Wardaningsih \& Salam, The concept of green open space function is divided into two, namely ecological and aesthetic functions. The ecological function of being closely associated with living things.
So the river serves as the ecology for rivers such as water, vegetation, soil, animals, and other constituent elements. Meanwhile, the aesthetic function is related to the beauty displayed from the river's face, such as the cleanliness, clarity of the river water, and the boundary of the river, which is seen from the natural formation of the limits and supporting elements. Zoning of river green open space, as shown in Figure 5.

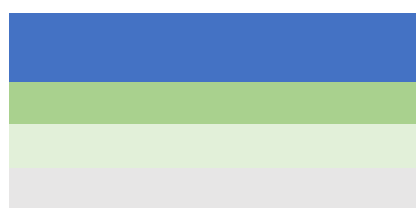

$$
\begin{aligned}
& \text { River } \\
& \text { Buffering Zone } \\
& \text { Conservation Zone } \\
& \text { Aesthetic Zone }
\end{aligned}
$$

Figure 5. Zone of River Green Open Space

Buffer zone is a green area which functions as a buffer. There is no activity, so that its maintenance is extensive. This buffer function is intended to maximize the flood overflow infiltration area through proper vegetation arrangement. This area will be developed as a vegetation area with ecological functions as a water absorber, soil and water protection, erosion prevention, oxygen production, reducing pollution, and solar radiation.

The conservation zone has many functions. The first, to protect the community from negative impacts around the river. The second is to preserve vegetation and animals around the river by making green open space that functions as a water catchment area. The third, to protect rivers from the effect of erosion by making retaining walls and arranging vegetation in areas that are steep slopes. The aesthetic zone provides an attractive and beautiful view of the riverbank to give a pleasing impression. The aesthetic function can be seen from the natural formation of the river and supporting vegetation [8].

\subsection{Riverfront}

According to Cliff $\mathrm{M}$ in Yang \& $\mathrm{Xu}$, the river is a place of relaxation, a place to relax, a place to contemplate, and a place for recreation. Green corridors on river banks can protect species, reduce water contamination, normalize climate change around the area [9]. Other benefits include improving a better quality of life, diverting water pressure on flood control, as drainage can work properly, and playing a role in urban development [10].

The concept of Public Accessibility of Riverfront (PAR) develops public spaces and comfortable access to the river banks. It makes use of natural and social resources, in this case, such as open spaces, visual corridors, sustainable ecology, and considering environmental friendliness [9]. According to Otto, 
McCormick, \& Leccese, in the construction of river banks, it is necessary to pay attention to the main principles, planning principles, and regional development principles on the river banks. This primary principle is made for good planning. The transformation in the river reclamation can cause pollution and threatens ecological conditions. Even there is no effort to improve the riverbank area's logical conditions. Even there is no effort to enhance the riverbank area to [10] :

1. The goals of ecological and economic development must be mutually beneficial.

2. Maintenance and restoration of natural features and functions of rivers.

3. Regeneration of river banks as natural spaces for humans.

4. A compromise is needed to achieve many goals.

5. Create a participatory-based riverside planning and design process.

\subsection{Reaching Resilience by Self Sufficient Approachment in Pandemic Era}

The National Academies defines resilience as "the ability to prepare and plan for, absorb, recover from, and more successfully adapt to adverse events". These abilities improve the capacity of cities to survive and thrive in the face of change. This definition recognizes the importance of taking actions and enhancing capabilities during different phases of the disaster risk management cycle and emphasizes the significance of learning and adaptation. It should be noted that resilience has various environmental, social, physical, and economic dimensions considered in the analysis [11].

In the Merriam-Webster dictionary, self-sufficient means being able to maintain itself without outside help and provide for itself. Meanwhile, in the Indonesian language, it means swasembada. A Self-Sufficient area will produce everything, which is the necessity of its residents' life by minimizing the impact on the surrounding environment. Self-Sufficient City has a close relationship with Ultimate Sustainable City, which requires more than just including a sustainability component [12].

Sustainable development has the purpose of creating and maintaining a prosperous social, economic, and ecological system. So there are close relationships which are the dependence of humans on ecosystems for their wealth and security. Besides, humans can also change the ecosystem into the expected conditions. Humans receive many from ecosystem processes, such as clean water and air, food production, fuel, Etc. However, irresponsible human activities can make ecosystems unable to provide all of these and negatively impact the process of meeting human needs, vulnerability, and security. It has shown that it has lost resilience [13].
As cite from Environmental Advisory Council to Sweden Government report as an input for The World Summit on Sustainable Development (WSSD) at Johannesburg, South Africa, 2002, state a new concept for a decade that the resilience importance for the development of people welfare. The fact showed a tight relationship between resilience, variety, and continuity of the socio-ecology system [13].

The socio-ecological system can absorb a more significant response to changes in the ecosystem without changing it fundamentally. When a significant transformation is unavoidable, resilience systems contain the components needed for reform reorganization. On the other hand, they can cope with, adapt, or reorganize without sacrificing the ecosystem's provision [13].

Developing socio-ecological resilience requires ecosystem understanding, which incorporates the knowledge of local users. The problem of resilience decreases due to human activity that does not pay attention to nature can be overcome by understanding the complex relationship between humans and nature, which creates opportunities for innovative technology and economic policies that aim to build resilience [13].

A diagram that shows the relationship between Selfsufficient and resilience can be obtained, as shown in figure 6 .

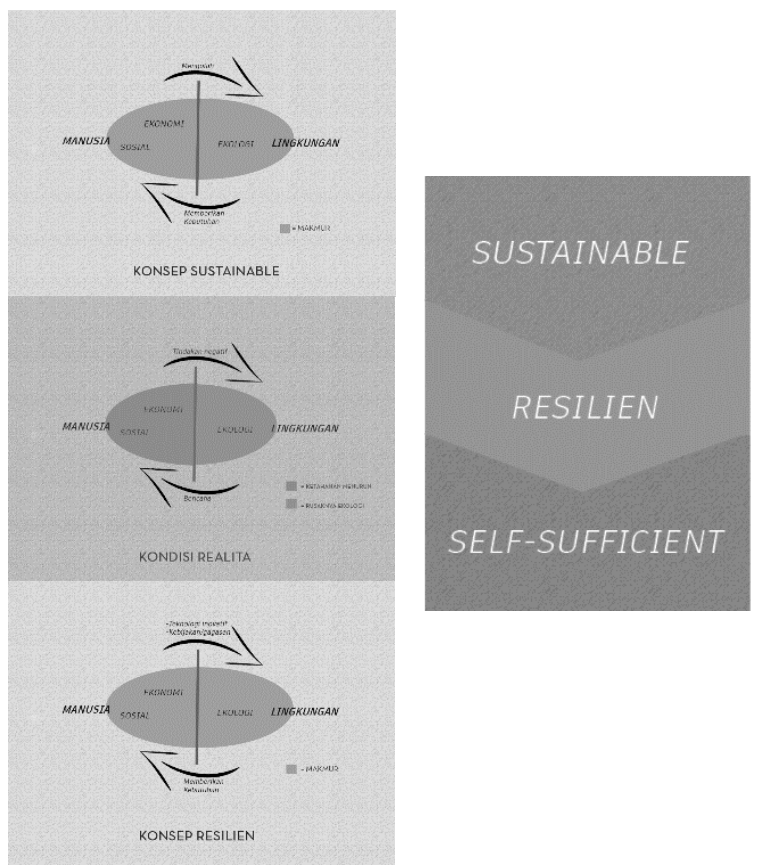

Figure 6. Relationship between Self-Sufficient and Resilience Diagram 
We can conclude that a self-sufficient settlement is a swasembada settlement, which is able to create and maintain the resilience of social, economic, and ecological systems in meeting the needs of life, so that in this case resilience both in terms of social, economic, and ecological can be fulfilled.

\section{METHOD}

The research method used is qualitative with a literature study approach and residential objects observation. The descriptive qualitative research method in this study is used to describe the location, as it relates to

1. The conditions of the infrastructure in the settlement,

2. The provision of infrastructure and the parties involved, and

3. The factors that affect the conditions of slums in Kampoeng Muharto.

\subsection{Collecting Data}

The primary data in this study is data that has been taken directly in the location of the case study. The data collected in various ways, specific to the required information. 1) Interviews are used to obtain data and information from individuals living in the vicinity of the environment; and 2) Documentation of data from the questionnaire and a photo collection, which supplements the primary data obtained through the interviews and observation. The second data is the literature method, previous research, or articles. The results that have got can be considered and provide treatment solutions.

\subsection{Data Analysis}

The method of analysis used in this study is the SWOT analysis method. Attributes are categorized as 1) strengths, which are advantageous attributes of the planning area that have not yet been maximally utilized or that have been neglected; 2) weaknesses, which are negative or compromising characteristics of the planning area; 3) opportunities which are broader positive possibilities that may be exploited on a future urbanrural/regional scale; and 4) threats, which are primarily external factors that threaten the success of the implementation.

As shown in the SWOT analysis in Table 1, decisions can be made over which potential of kampong that will consider as a character of kampong vertical.
Table 1. SWOT Analysis of Kampung Muharto

\begin{tabular}{|c|c|c|}
\hline ' & Aspect & Description \\
\hline 1. & Strength & $\begin{array}{l}\text { - Kampong Muharto had } \\
\text { traditionally been the location of } \\
\text { the tombs of Chinese Indonesians } \\
\text { - Strategic location } \\
\text { - Communities have a good } \\
\text { entrepreneurial spirit and } \\
\text { community work as traders. } \\
\text { - Potential public knowledge about } \\
\text { the media for planting plants } \\
\text { (vertical garden) }\end{array}$ \\
\hline 2. & Weakness & $\begin{array}{l}\text { - } \text { The absence of vacant land for } \\
\text { public facilities } \\
\text { - Minimal supporting facilities } \\
\text { - Poor utilization and not well } \\
\text { organized } \\
\text { - Minimal public awareness of } \\
\text { hygiene } \\
\text { - The river banks in this area have } \\
\text { not been well managed } \\
\text { Most are low-income people }\end{array}$ \\
\hline 3. & Opportunity & 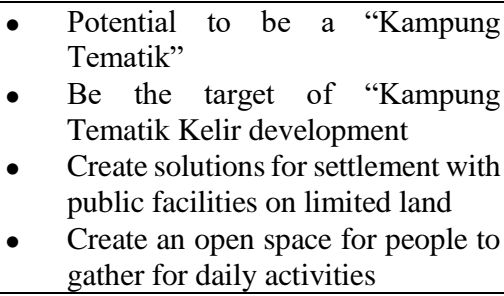 \\
\hline 4. & Threat & 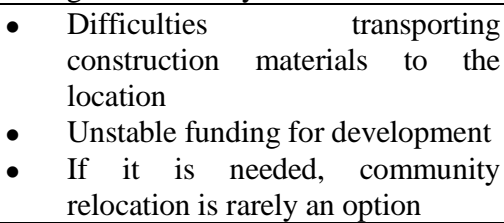 \\
\hline
\end{tabular}

Source: Data Analysis, 2020

\section{RESULT 4.1 Result of SWOT Analysis}

Table 2 indicates the suitability between strategy and aspects of general criteria. The development strategy for vertical kampong must be easily adapted to the local people. It refers to the planning and design based on people's needs to achieve sustainability. The meaning and identity of settlement can still stand out. This strategy is classified based on the aspects of resilience studied in the analysis.

Kotalama village RT. 5 RW. 06 is one of the densely populated settlements in the landslide-prone area. Before the existence of settlements on the riverbanks, the area included two ecosystems that coexist with each other. The sustainability of river ecosystems is influenced by the land ecosystem and the riparian ecosystem as their transitional area. When the land ecosystem changes its function as a settlement, then those changing 
circumstances of the river ecosystem change. Now, a clean river is coated with household waste thrown directly into the river. Not only that, but also the garbage piled up on the riverbank. As more settlements grow over the riverbank, so more wastes and garbage dumping in the river area. This causes disbalance between the two ecosystems and can lead to natural problems leading to disaster. One of them is floods and landslides. Therefore, the settlements along the riverbank become a vulnerability to ecological aspects.

Table 2. Result of SWOT Analysis

\begin{tabular}{|c|c|c|}
\hline $\begin{array}{l}\text { INTERNAL } \\
\text { FACTORS }\end{array}$ & $\begin{array}{l}\text { Strength (S) } \\
\text { Kampong Muharto } \\
\text { had traditionally } \\
\text { been the location of } \\
\text { the tombs of Chinese } \\
\text { Indonesians } \\
\text { Strategic location } \\
\text { bordering on direct } \\
\text { the Brantas River } \\
\text { Communities have a } \\
\text { good entrepreneurial } \\
\text { spirit and community } \\
\text { work as traders. } \\
\text { The community have } \\
\text { knowledge about } \\
\text { plant media (vertical } \\
\text { garden) }\end{array}$ & $\begin{array}{l}\text { Weakness (W) } \\
\text { - The absence of vacant land } \\
\text { for public facilities } \\
\text { Poor utilization and not well } \\
\text { organized. } \\
\text { - High humidity because of } \\
\text { the rapid arrangement of } \\
\text { settlement. } \\
\text { - The river banks in this area } \\
\text { have not been well managed. } \\
\text { - Most are low-income people } \\
\text { People's habits throw the } \\
\text { rubbishes to the river or river } \\
\text { banks directly. } \\
\text { - River existence that not } \\
\text { ecological } \\
\text { - Located in the limited land }\end{array}$ \\
\hline $\begin{array}{l}\text { Opportunity }(\mathbf{O}) \\
\text { Potential to be a } \\
\text { "Kampung Tematik" } \\
\text { Be the target of } \\
\text { "Kampung Tematik } \\
\text { Kelir's development } \\
\text { Create solutions for } \\
\text { settlement with public } \\
\text { facilities on limited } \\
\text { land } \\
\text { Create an open space } \\
\text { for people to gather for } \\
\text { daily activities }\end{array}$ & $\begin{array}{l}\text { Developing vertical } \\
\text { kampong as the } \\
\text { thematic Kampoeng } \\
\text { Kelir with its } \\
\text { specific character } \\
\text { Developing the } \\
\text { potential knowledge } \\
\text { and spirit of } \\
\text { community in } \\
\text { entrepreneurial and } \\
\text { plant media }\end{array}$ & $\begin{array}{l}\text { - Create the river banks be the } \\
\text { riverfront which consist } \\
\text { of green open space and } \\
\text { public open space } \\
\text { - Create a trash bank with a } \\
\text { recycling management } \\
\text { - Give access for sun and wind } \\
\text { flow in the vertical kampong }\end{array}$ \\
\hline $\begin{array}{l}\text { Difficulties trans- } \\
\text { porting construction } \\
\text { materials to the } \\
\text { location } \\
\text { The site is prone to } \\
\text { landslides } \\
\text { Fear that the Brantas } \\
\text { River will overflow } \\
\text { into the housing area }\end{array}$ & $\begin{array}{l}\text { Using recycling and } \\
\text { lightweight material } \\
\text { to minimize } \\
\text { landslide risk. } \\
\text { Provide the rain } \\
\text { garden along the } \\
\text { river banks } \\
\text { Engineering the } \\
\text { retaining wall into } \\
\text { bio retaining wall }\end{array}$ & $\begin{array}{l}\text { - Create a green open space } \\
\text { that connected the river and } \\
\text { settlement area. } \\
\text { - Increase the community } \\
\text { economy by generating } \\
\text { thematic kampong as a } \\
\text { recreational area. }\end{array}$ \\
\hline
\end{tabular}

Source: Result, 2020

In addition, densely populated settlements will have the potential to be more humid than other settlements. Further drainage lines and household waste disposal pipes are not organized, increasing the potential for propagating bacteria and viruses. Humid environment conditions are more prevalent in transmitting disease, resulting in a vulnerability to residential health aspects.

In another aspect, the river's densely populated regions are still dominated by low-income populations. This also becomes one of the subjects which must be considered to the settlement design concept. Yusing stated that in forming a residential building design, we must not abandon the basis of settlement in the local population's economic aspect. The economy of society must also be considered in the design. The population in the case study whom the majority as traders and their knowledge of the planting media become an enormous potential for the residential area. By developing the lacking and making potential of the existing settlement as a strength of the design concept, the design concept in economic resilience in settlements can be achieved.

The residential area's village characteristics are still visible, though its district was in the city area. The residents can see it make the street a communal space with various activities, such as cooking together, drying clothes, women talking, and sitting relaxed, enjoying the riverside's atmosphere. The presence of the village is due to the informality of a formal rule. This informal character can be the potential in a settlement design, by providing communal spaces that facilitate this form of socialization. So they can have residential resilience in the social aspect. From each of the aspects described above, it can be detailed in the design strategy table 3 .

Table 3. Strategy Design Being Categorized in Resilence Aspects

\begin{tabular}{|l|l|}
\hline Strategy from SWOT & Catagory of Resilience \\
\hline - Dwellings that are able to adapt to & Ecological Resilience \\
the risk of landslides prone. & \\
Residences that do not damage the & \\
- Residences that minimizes the & \\
necessary amount of energy & \\
- Residences that provide waste bank \\
facilities as well as waste recycling & \\
- Give access to sun and wind flow in & Health Resilience \\
the vertical kampong & \\
\hline - Developing vertical kampong as the \\
thematic Kampoeng Kelir with its & Economic Resilience \\
specific character & \\
- Developing the potential knowledge \\
and spirit of community in \\
entrepreneurial and plant media
\end{tabular}

Source: SWOT Strategy Analysis, 2020

\subsection{Result of Self Sufficient Approach}

As discussed above, the target of this problem is the resilience of settlements in DAS. Achieving resilience classified into ecological, economic, social, and health resilience, approach design strategies were used, which became parameters for creating a vertical village 
concept. In analyzing and forming a resilience vertical village design concept, a self-sufficient approach is used. A Self-Sufficient area will produce everything that is the lifeblood of its community by minimizing the impact on the surrounding environment. It can be drawn a red line between the achieving of settlement resilience and the Self-Sufficient approach.

A self-sufficient approach is also called the ultimate sustainable. Because self-sufficient is more than just including the elements of sustainability into it. From the diagram of the relationship between self-sufficient and resilience, two elements are interrelated that lead to selfsufficient, namely sustainability and resilience. These related to the first statement that states ultimate sustainability, referring not only to include sustainable elements but also to include resilience elements in a settlement to be said to be self-sufficient. So 2 points can be taken from self-sufficient to be a parameter of the design concept, sustainability, and resilience.

The above has been mentioned that self-sufficient is another meaning of swasembada. Swasembada is an area that can fulfill its own needs, its people have been able to utilize and develop natural resources, and it is potential according to regional development activities. In this regard, we know that the case study's residential areas are being one of the targets for the thematic village development of Malang city. So it could be the potential in achieving economic resilience. Because of being a thematic village, it can be increasing the population's income.

The concept of self-sufficient to fulfill the settlement's resilience will involve the role of the community itself. So the community locality's potential character is used in forming an economic fulfillment strategy by maintaining the village characters that are settled within neighborhoods. The community can enjoy and be creative in creating resilience for their settlements, and this is what the existence of thematic villages of character capable of independent resilience would like to convey. Therefore, it can be drawn 2 points related to this matter, namely interactive or a close relationship between society's character and the fulfillment of economic resilience. The second points are enjoyable or how people can enjoy and be creative in creating resilience for their settlements. The Table 4 shows the results of SWOT analysis with a self-sufficient approach study.

Table 4. Design Strategies Analysis based Self-Sufficient Approach

\begin{tabular}{|c|c|c|c|}
\hline Strategy from SWOT & Aspect & $\begin{array}{c}\text { Analysis based on } \\
\text { Self -Sufficient } \\
\text { Approaching } \\
\end{array}$ & $\begin{array}{l}\text { The aspect of } \\
\text { Self -Sufficient }\end{array}$ \\
\hline $\begin{array}{l}\text { - Dwellings that are able to adapt to the risk of landslides prone. } \\
\text { - Residences that do not damage the river's ecosystem } \\
\text { - Residences that minimizes the necessary amount of energy } \\
\text { - Residences that provide waste bank facilities as well as waste recycling }\end{array}$ & $\begin{array}{l}\text { Ecological } \\
\text { Resilience }\end{array}$ & \multirow[t]{2}{*}{$\begin{array}{l}\text { Settlements that } \\
\text { have attention to } \\
\text { physical health and } \\
\text { fulfill the needs of } \\
\text { their community by } \\
\text { managing and } \\
\text { maintaining the } \\
\text { ecology of their } \\
\text { surrounding } \\
\text { environment by } \\
\text { sustainable design. }\end{array}$} & \multirow[t]{2}{*}{$\begin{array}{l}\text { Sustainabality } \\
\text { and Resilience }\end{array}$} \\
\hline - Give access to sun and wind flow in the vertical kampong & $\begin{array}{l}\text { Health } \\
\text { Resilience }\end{array}$ & & \\
\hline $\begin{array}{l}\text { - Developing vertical kampong as the thematic Kampong Kelir with its } \\
\text { specific character } \\
\text { - Developing the potential knowledge and spirit of community in } \\
\text { entrepreneurial and plant media } \\
\text { - Increase the community economy by generating thematic kampong as a } \\
\text { recreational area. }\end{array}$ & $\begin{array}{l}\text { Economic } \\
\text { Resilience }\end{array}$ & \multirow[t]{2}{*}{$\begin{array}{l}\text { A design that } \\
\text { develops the } \\
\text { localities from the } \\
\text { community has } \\
\text { created thematic } \\
\text { village to meet both } \\
\text { economic and social } \\
\text { needs. }\end{array}$} & \multirow[t]{2}{*}{$\begin{array}{l}\text { Interactive and } \\
\text { Enjoyable }\end{array}$} \\
\hline $\begin{array}{l}\text { - Making river banks into social facilities, consist of green open space and } \\
\text { public open space } \\
\text { - A vertical village that maintains the kinship of village locality }\end{array}$ & $\begin{array}{l}\text { Social } \\
\text { Resilience }\end{array}$ & & \\
\hline
\end{tabular}

Source: Author, 2020 
From the analysis result in table 4, it can be concluded that this vertical kampong has two functions, which are the primary function and the supporting function. As its main function is a settlement, then the second function is a thematic village to attract tourists to come and increase the population's income. Two users in this vertical village need to be considered: residents and tourists. These resident users' design outputs can be obtained, including settlements, waste banks, waste management, and communal recreational spaces. Meanwhile, the design output from tourist users is waterfront and public open space.

\subsection{Result of Concept Design}

Table 5. the Design Concept

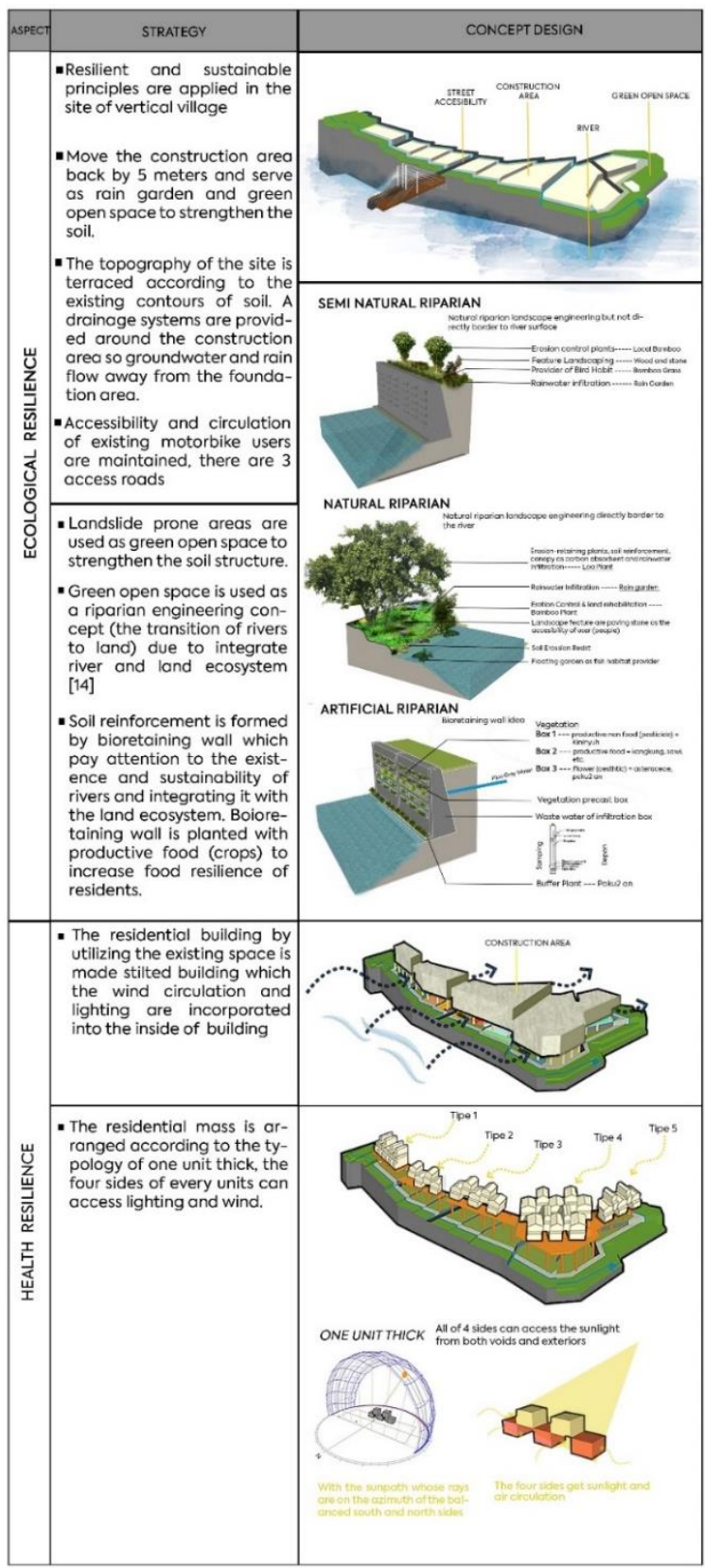

Table 6. Concept Result

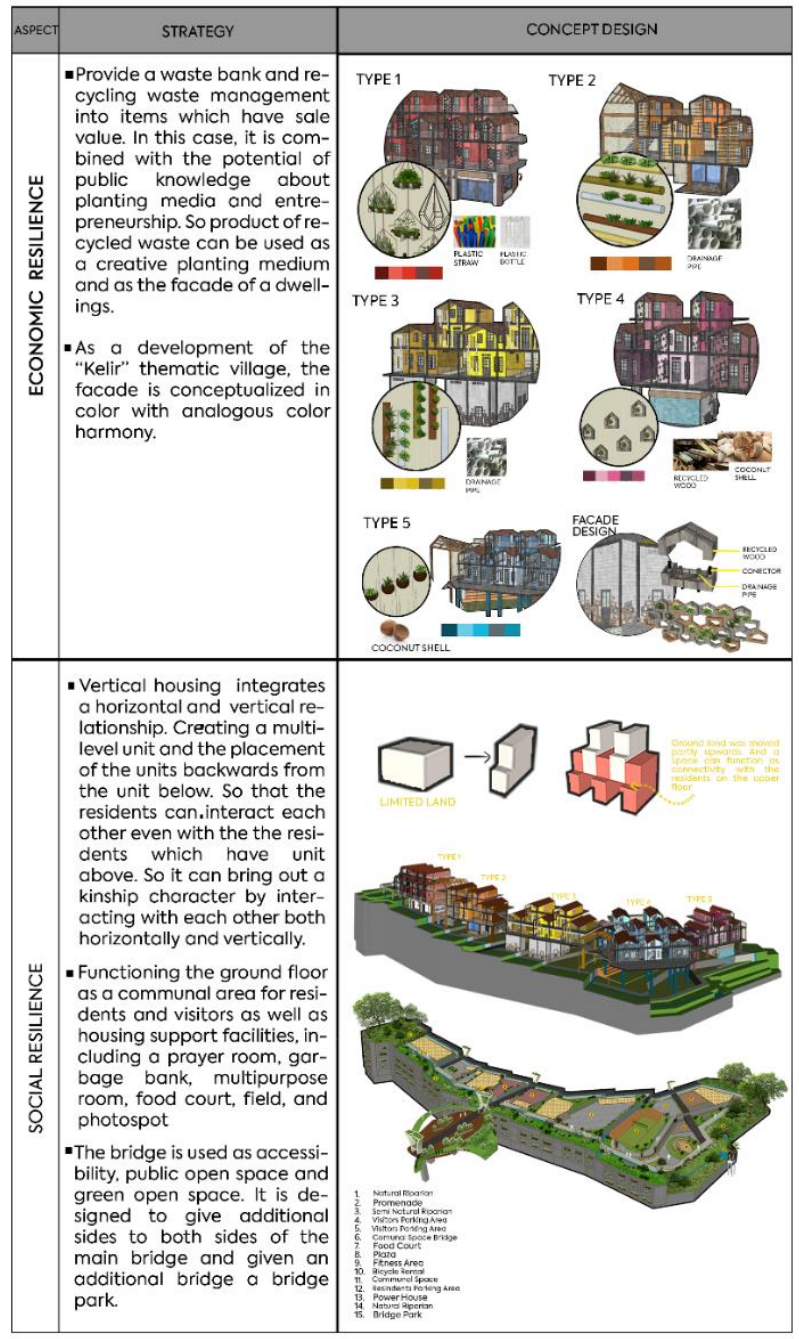

\section{CONCLUSION}

Given the challenges of land constraints that have the potential to landslide and the maintenance of environmental quality, there is a required intensification of community resilience in the vertical village concept. Through the SWOT analysis method, inputs and options were offered to solve problems. A self-sufficient approach study is needed in making a design analysis of vertical village concept design on limited land, especially on riversides. By understanding the aspects of settlement resilience that are integrated with a selfsufficient approach study, the best vertical village concept design can be realized. A Self-sufficient settlement can withstand resilience in social, economic, ecological, and health aspects, especially facing pandemic Covid-1. This design applies the local character of residents, such as entrepreneurs spirit as traders and knowledge about planting media. It also makes residential landscapes as riparian ecosystems, which is transitional river and land ecosystems, and making the potential of both of them as public spaces 
served to users by riverfront promenades. It can be an appeal to form a thematic village as the Malang city government has planned to tackle the problem of slum settlements on the riverbank. The thematic village concept could become a tourist attraction and improve the standard of living and income of the local community.

\section{REFERENCES}

[1] Ischak, Urbanisasi dan Dampaknya pada Lingkungan, in: Jurnal-Humaniora UGM, vol. 13, no. 2,2020 , pp. $275-283$.

[2] K. Nesbitt, Theorizing a new agenda for architecture, New York: Princeton Architectural Press, 1996, pp. 430-439.

[3] R. Ghiffari, Dampak Populasi Dan Mobilitas Perkotaan Terhadap Penyebaran Pandemi Covid-19 Di Jakarta, vol. 9, no. 1, Tunas Geografi, 2020, p. 81

[4] A. Dorn, R. Cooney, M. Sabin, Covid-19 Exacerbating Inequalities In The US, The Lancet, vol. 395, no. 10232, 2020, pp. 1243-1244.

[5] Data Monografi, Kelurahan Kotalama, Kecamatan Kedung Kandang, Kota Malang, Malang, 2020.

[6] F. Augugliaro, et al., The Flight Assembled Architecture installation: Cooperative construction with flying machines, IEEE Control Systems, vol. 34, no. 4, 2014, pp. 46-64.

[7] S. Wardiningsih, B. Salam, Perencanaan Rth Sempadan Sungai Ciliwung D I Kawasan Kampung Pulo Dan Bukit Duri Jakarta, Nalars, vol. 18, 2019, no. 1 , p. 65 .
[8] Y. Che, K. Yang, T. Chen, Q. Xu, Assessing a riverfront rehabilitation project using the comprehensive index of public accessibility, Ecological Engineering, vol. 40, 2012, pp. 80-87.

[9] Y. Asakawa, Chemosystematics of the Hepaticae, ChemInform, vol. 35, 2004, no. 26.

[10] B. Otto, K. McCormick and M. Leccese, Ecological riverfront design : restoring rivers, connecting communities, American Planning Association, 2004, pp. 155-170.

[11] A. Sharifi, Y. Yamagata, A Conceptual Framework for Assessment of Urban Energy Resilience", Energy Procedia, vol. 75, 2015, pp. 2904-2909.

[12] P. Bingham-Hall, Garden city. Mega city. Singapore: Pesaro Publishing, 2016.

[13] C. Folke, S. Carpenter, T. Elmqvist, L. Gunderson, C. Holling, B. Walker, Resilience and Sustainable Development: Building Adaptive Capacity in a World of Transformations, in: AMBIO: A Journal of the Human Environment, vol. 31, no. 5, 2002, pp. 437-440.

[14] A. Mosyaftiani, Kaswanto, H. Arifin, Bio-Retaining wall as an adaptive design of constructed riverbank into sustainable urban riparian landscape management, in: IOP Conference Series: Earth and Environmental Science, vol. 179, 2018, pp. 012015.

[15] Sunrise, sunset, dawn and dusk times around the World, Gaisma, 2020.

[16] Overview - Google Earth, Google Earth, 2020. 